\title{
Peran K.H. A. Muhammad Isa pada Tahun 1989-2021 dalam Perwujudan Islam Moderat di Cianjur Selatan
}

\author{
Alwan, Mahrus As'ad, Muhammad Riza \\ Program Studi S1 Sejarah dan Peradaban Islam, Fakultas Adab dan \\ Humaniora, UIN Sunan Gunung Djati Bandung \\ Email: rasyidalwan368@gmail.com
}

\begin{abstract}
K.H. A. Muhammad Isa was very instrumental in spreading the teachings of moderate Islam in South Cianjur. Practically, he took moderate steps as the best effort to address the differences in views between the conservative and modernist camps in responding to the changing times. He was very instrumental in translating the syarah texts of Arabic books, making them easy to understand and widespread among the Ulama of Cianjur Regency. He is also a Falak Ulama and a member of the Hisab and Rukyat Agency the Ministry Religion of the Republic Indonesia, thus making him always involved with the Ministry Religion of the Republic Indonesia in determining the new moon and one Shawwal. This paper tries to reveal the progress of K.H. A. Muhammad Isa in the Embodiment of moderate Islam in South Cianjur. To obtain valid data, the method used in this research is a historical research method, which is a systematic procedure or technique with the principles and rules of History. The technique in question includes several steps, including: selection of sources (heuristics), internal and external criticism (verification), data analysis and interpretation (interpretation), and presentation in written form (historiography). With this paper, future generations of Muslims are expected to be able to take role models from the figures discussed and be able to represent the attitude of religious moderation as a pillar of national integration; the creation of a tolerant and harmonious religious life so as not to cause national disintegration.
\end{abstract}

Keywords: Cianjur, Moderate Islam, Muhammad Isa.

\section{Pendahuluan}

Dalam sejarah keislaman, dinamika perkembangan pemikiran dunia Islam senantiasa dihadapkan pada aksi tarik menarik antara kelompok Islam berbasis konservatif ${ }^{1}$ atau pendukung nilai-nilai tradisional dengan kelompok

\footnotetext{
1 Islam konservatif adalah sebuah paham umat muslim yang mendukung nilai-nilai tradisnional. Sebagai contoh, paham ini terdapat pada ulama-ulama Nusantara sebelum terjadinya gerakan pemikiran modern dunia Islam, yang mana mereka menganggap bahwa gerakan modernisasi dalam dunia Islam tidak perlu dilakukan. Mereka menjadikan segala susuatu yang ada pada masa kegemilangan peradaban Islam abad klasik sebagai patokan
} 
Islam yang berbasis modernisme; ${ }^{2}$ antara Islam statis dan Islam dinamis. Mereka yang mengklaim sebagai golongan tradisionalis meyakini bahwa diskursus dalam ajaran Islam, baik dalam lingkup teoritis maupun praktis telah berakhir pada masa kehadiran ilmuwan dan pemikir keislaman terdahulu. Tugas dan kewajiban kelompok ini mempunyai pandangan keagamaan yang biastekstual, normatif, dan mengedepankan pembacaan literal. Karena itulah, para penganut paham modernis memandangnya sebagai suatu pemikiran yang kaku, jumud, dan cenderung monoton. ${ }^{3}$

Berbanding terbalik dengan Islam Konservatif, yaitu Islam Modernism. Aliran ini merujuk pada tradisi keislaman yang memprioritaskan semangat pembaharuan, reformasi, dinamis, serta adaptif terhadap perkembangan zaman. Secara umum, gerakan pemikiran Islam Modernis memiliki ciri khas keislaman yang menekankan pembacaan kritis dan progresif. Di sisi lain, semangat pembaharuan Islam modernis seringkali menuai perdebatan, bahkan kecurigaan, khususnya dari kelompok Islam konservatif. Kecurigaan itu dilatarbelakangi oleh kekhawatiran, khawatir jika paham keislaman yang diyakini oleh kelompok modernis itu menyimpang dari ajaran pokok al-Qur'an dan yang telah diajarkan serta di contohkan Rasulullah SAW. Dalam konteks keislaman global, corak keislaman ini mulai tumbuh intens pada awal abad ke-20 M, yaitu setelah munculnya gerakangerakan pembaharuan pemikiran Islam di beberapa negara yang mayoritas berpenduduk muslim, salah satunya Indonesia. ${ }^{4}$

Menghadapi kenyataan terhadap adanya perbedaan antara dua kutub yang saling bertentangan ini, yaitu antara aliran Islam konservatif dan Islam modernis, maka munculah Ulama-ulama moderat yang berperan sebagai

\footnotetext{
dalam menjalani kehidupan beragama, dan yang tidak ada serta tidak dilakukan pada masa itu dianggap menyalahi ajaran Islam.

${ }^{2}$ Kelompok Islam modern ialah sekelompok muslim yang melakukan suatu proses atau usaha untuk mengadakan perubahan-perubahan dalam lingkungan ataupun masyarakat yang berlainan dari keadaan sebelumnya. Hal ini terlihat dari sifatnya yang maju, progresif, serta adaptif terhadap perubahan zaman.

${ }^{3}$ Abd Hannan et al., "Islam Moderat Dan Tradisi Popular Pesantren : Strategi Penguatan Islam Moderat Di Kalangan Masyarakat Madura Melalui Nilai Tradisi Popular Islam Berbasis Pesantren Moderate Islam and Popular Pesantren Tradition: Strategy for Strengthening Moderate Islam," Jurnal Sosiologi Dialektika 13, no. 2 (2018): 152-68, https://ejournal.unair.ac.id/DIALEKTIKA/article/view/19149.

${ }^{4}$ Kamal Maarif, Syamsudin, "Satu Islam Banyak Jalan: Corak-Corak Pemikiran Modern Dalam Islam," in Satu Islam Banyak Jalan: Corak-Corak Pemikiran Modern Dalam Islam, ed. Amin Nurdin (Yogyakarta: Pustaka Pelajar, 2020), 6.
} 
penengah diantara keduanya. ${ }^{5}$ Beberapa Ulama moderat yang dianggap telah berjasa besar dalam mewujudkan Islam Moderat, antara lain: ${ }^{6}$ Abdurrahmaan Wahid (Gus Dur), Buya Syafi'i, Mustofa Bisri, Quraish Shihab, Ahmad Muwafiq, dan K.H. A. Muhammad Isa yang berkiprah di Cianjur Selatan, Jawa Barat.

A. Muhammad Isa Adalah cendikiawan muslim yang sangat gigih dalam mencetak generasi muda Islami yang moderat. Ia sangat berjasa dalam menerjemahkan tukilan syarah Kitab-kitab berbahasa Arab, sehingga mudah dimengerti dan menyebar luas dikalangan Ulama Kabupaten Cianjur. ${ }^{7}$ Ia adalah Ulama Falak serta merupakan Anggota Badan Hisab dan Rukyat Kementerian Agama Republik Indonesia pada periode $2006^{8}-2015 .{ }^{9}$ Dengan demikian, ia selalu dilibatkan Kementerian Agama Republik Indonesia dalam menentukan awal Ramadhan dan satu Syawal. Kiprah A. Muhammad Isa dalam dunia Islam tak cukup sampai di situ, ia juga merupakan pengasuh Pondok Pesantren Al-Ihya yang berlokasi di Kampung Cibadak, Tanggeung, Kabupaten Cianjur. Seiring berjalannya waktu, pondok pesantren itu berkembang dengan pesat dan berhasil memperoleh kepercayaan dari para orangtua santri khususnya, maupun masyarakat Cianjur pada umumnya, sehingga muridnya kian bertambah. Sebagai Ulama Moderat, ia mengembangkan dan mendirikan lembaga pendidikan formal, diantaranya:

\footnotetext{
${ }^{5}$ Hannan et al., "Islam Moderat Dan Tradisi Popular Pesantren : Strategi Penguatan Islam Moderat Di Kalangan Masyarakat Madura Melalui Nilai Tradisi Popular Islam Berbasis Pesantren Moderate Islam and Popular Pesantren Tradition: Strategy for Strengthening Moderate Islam."

${ }^{6}$ Tagar.id, "Gus Dur Dan Empat Tokoh Islam Moderat Asal Indonesia," 22 Agustus, 2019, https://www.tagar.id/gus-dur-dan-empat-tokoh-islam-moderat-asal-indonesia\%0A\%0A.

${ }^{7}$ Syarif Hidayatullah, "R. Muhammad Isa, Ulama Falak Cianjur Meninggal Dunia," 11 April, 2021, https://www.google.com/amp/s/pakuanraya.com/r-muhammad-isa-ulama-falaqcianjur-meninggal-dunia/amp/ .

8 Menteri Agama Republik Indonesia, "Keputusan Menteri Agama Republik Indonesia Nomor 483 Tahun 2006 Tentang Penunjukan Personalia Badan Hisab Dan Rukyat Departemen Agama Tahun 2006" (Jakarta, 2006), https://www.google.com/search?q=penetapan+anggita+bafan+hisab+dan+rukyat+2006\&oq $=$ penetapan + anggita + bafan + hisab + dan + rukyat $+2006 \&$ aqs $=$ chrome..69i57.10003j0j9\&client $=$ ms-android-samsung\&sourceid $=$ chrome-mobile $\&$ ie $=U T F-8$.

9 Menteri Agama Republik Indonesia, "Keputusan Menteri Agama Republik Indonesia Nomor 56 Tahun 2010 Tentang Pembentukan Pengurus Badan Hisab Dan Rukyat Kementerian Agama 2010" Tahun (Jakarta, 2010), https://www.google.com/url?sa=t\&source=web\&rct=j\&url=https://kepri.kemenag.go.id/publ ic/files/kmapma/szqx1419410452.pdf\&ved=2ahUKEwi4wsah95f0AhVQWX0KHQOOCuo QFnoECAYQAQ\&usg=AOvVaw3z6GIOVSeltshWpIPVQXj6.
} 
Madrasah Ibtidaiyah (MI) Salafiyah, Madrasan Tsanawiyah (MTs) Al-Ihya, dan Madrasah Aliyah (MA) Al-Ihya, yang letaknya masih berada di kompleks Pesantren Al-Ihya Cibadak. ${ }^{10}$

Penelitian ini berfokus pada korelasi antara kiprah A. Muhammad Isa dengan perwujudan Islam moderat di Cianjur Selatan. Tujuan penelitian ini ialah untuk mengetahui dan mendeskripsikan perilaku A. Muhammad Isa dalam menjalankan kewajibannya sebagai umat islam yang sekaligus telah memberikan kontribusi besar terhadap nasib pengajaran syariat Islam di Cianjur Selatan, khususnya dalam perwujudan moderasi beragama. Belum ditemukan sejumlah literatur yang telah membahas kiprah A. Muhammad Isa dalam perwujudan islam moderat di Cianjur Selatan, sehingga penulis merasa perlu adanya literatur yang menyajikan kiprah seorang Ulama cendikiawan yang sangat besar jasanya dalam menghidupkan moderasi beragama di Cianjur Selatan.

Dalam agama Islam, menuntut ilmu guna memperoleh berbagai ilmu pengetahuan merupakan sebuah kewajiban bagi setiap manusia, baik laki-laki maupun perempuan. Agama Islam sangat menghormati setiap orang yang berupaya memperoleh ilmu pengetahuan, sebab ilmu adalah kunci untuk memperoleh amal kebaikan; tidak sempurna agama dan amal ibadah seorang muslim tanpa dibarengi ilmunya. ${ }^{11}$ Akan tetapi, secara praktis setiap insan yang berilmu pengetahuan tentunya harus dibarengi oleh kesadaran terhadap pentingnya sikap moderat dalam menghadapi setiap perbedaan. Atas dasar inilah, penelitian ini dilakukan dengan mengangkat tema seorang tokoh ulama besar dari Cianjur yang memiliki perhatian serta kepedulian yang sangat besar dalam perwujudan Islam moderat di Cianjur Selatan.

\section{Metode Penelitian}

Metode penelitian yang digunakan untuk memperoleh data pada penyusunan artikel ini adalah metode penelitian sejarah. Langkah-langkah praktis dalam metode penelitian sejarah ini paling tidak memiliki empat langkah utama yang meliputi: (1) heuristik, (2) kritik atau verifikasi, (3) interpretasi atau penafsiran, dan (4) historiografi (Notosusanto, 1978: 35-43;

\footnotetext{
10 Alwan, "Wawancara Sehari Dengan Cep Muhammad Ridwan Mengenai K.H. A. Muhammad Isa" (Cianjur, October 10, 2021), 2.

${ }^{11}$ Cicik Novita, "Memahami Makna Menuntut Ilmu Dan Keutamaanya Dalam Islam," 30 Mei, 2021, https://www.google.com/amp/s/amp.tirto.id/memahami-makna-menuntut-ilmudan-keutamaannya-dalam-islam-ggpX .
} 
Gottschalk, 1983: 34; Kuntowijoyo, 1995: 89-105; Kartodirjo, 1982: 63-67). ${ }^{12}$ Heuristik, adalah proses mencari dan menemukan sumber informasi, yaitu dengan cara mendatangi dan mewawancarai saksi-saksi pada tokoh yang dibahas. Data yang termuat dalam penelitian ini dikategorikan sebagai data kualitatif. Dengan demikian, teknik analisis data yang digunakan dalam penelitian ini adalah teknik analisis data kualitatif, dan sumber yang digunakan adalah sumber primer. Kritik atau verifikasi, yaitu proses verifikasi atau kritik sumber. Dalam proses ini, setelah diperolehnya data dari berbagai sumber, peneliti berusaha mencari kebenaran dan keabsahan data yang diperoleh. Interpretasi atau penafsiran, dalam proses ini, peneliti berusaha menafsirkan dan membandingkan data yang telah diperoleh dari berbagai sumber untuk memperoleh kebenaran data yang akurat dan berimbang. Langkah akhir dalam metode penelitian sejarah ini disebut historiografi, yaitu peulisan laporan hasil penelitian persitiwa sejarah yang telah dilakukan. Pada tahap penulisan ini, penulis berupaya untuk memberikan gambaran proses penelitian dari awal sampai akhir, penyajian informasi inti dan disertai dengan penarikan kesimpulan.

\section{Hasil dan Pembahasan}

\section{Biografi A. Muhammad Isa}

A. Muhammad Isa lahir di Sindangbarang pada tanggal 30 September 1930/ 7 Jumadil Awal 1349 H, putra dari pasangan Ust. Muhammad Anwar dan Hj. Nuriyah. Pasca kelahirannya, sang kakek, H. Tohir menyematkan nama Acep Isa Hidayat untuknya. Pada saat masih balita, A. Muhammad Isa tidak tinggal bersama ayahnya dikarenakan orangtuanya sudah bercerai. Pada akhirnya, A. Muhammad Isa dibawa oleh ibunya ke Cihamirung untuk tinggal dan menetap di sana sampai usia tiga tahun. Setelah mencapai usia tiga tahun, A. Muhammad Isa dibawa oleh kakeknya, H. Tohir ke Sindaangbarang untuk tinggal dan menetap bersamanya. Disana, A. Muhammad Isa memperoleh pendidikan umum melalui Sekolah Rakyat (SR), serta pendidikan keagamaan di Madrasah Diniyah Takmiliyah Awaliyah (DTA), yang di asuh oleh mualim Zarqani. Setelah menamatkan pendidikan di Sekolah Rakyat dan Madrasah Diniyah Takmiliyah Awaliyah (DTA), atas petunjuk dan saran dari sang kakek, A. Muhammad Isa berangkat ke Cibadak untuk menemui ayahnya, Ust.

\footnotetext{
${ }^{12}$ Sugeng Priyadi, Sejarah Lokal: Konsep, Metode, Dan Tantangannya, ed. Dian Qamajaya (Yogyakarta: Ombak, 2015).
} 
Muhammad Anwar guna memperoleh pendidikan agama lebih mendalam. Saat itu, Ust. Muhammad Anwar merupakan guru sekaligus pengasuh Pondok Pesantren Cibadak. Pada saat itulah, A. Muhammad Isa belajar kitab-kitab dasar ilmu Agama dan Bahasa Arab. ${ }^{13}$

Setelah beberapa saat belajar dengan ayahnya, ia pamit untuk pergi belajar kepada H. Ali Abas di Pagermaneuh, Gunung Puyuh, Sukabumi, guna mendapat pendidikan agama di Pondok Pesantrennya. Namun, pendidikan agama yang ia tempuh disana tidak berselang lama dikarenakan H. Ali Abas meninggal dunia; Ali Abas menjadi korban kekejian tentara kolonial Belanda. Pada akhirnya, A. Muhammad Isa berhenti menuntut ilmu di Gunung Puyuh, Sukabumi dan melanjutkan pesantrennya di Buni Kasih selama lebih kurang satu tahun lamanya. Setelah itu, ia meneruskan pendidikan keagamaannya di Pesantren Ciharashas, Kabupaten Cianjur. Ia menimba ilmu di Ciharashas lebih kurang selama 3 tahun lamanya, kemudian melanjutkannya ke Pesantren Gudang, Tasikmalaya dalam waktu yang relatif lebih singkat. Setelah A. Muhammad Isa menyelesaikan pendidikan keagamaan di Pesantren GudangTasikmalaya, ia kembali ke kampung halamannya di Cibadak dan bermukim di sana. Di Cibadak, ia mengamalkan ilmu yang telah diperolehnya semasa menempuh pendidikan keagamaan dibeberapa Pondok Pesantren yang telah di pijaki, ia turut memberikan pengajaran keagamaan di Pesantren Cibadak yang dipimpin oleh ayahnya, Ust. Muhammad Anwar. ${ }^{14}$ Dan pada perkembangan selanjutnya, lebih kurang pada tahun 1960-an ia mendirikan Madrasah Ibtidaiyah (MI) sebagai upaya untuk merespons tuntutan zaman dan memenuhi kebutuhan masyarakat. ${ }^{15}$

Sebelum Ustadz Muhammad Anwar wafat, yaitu pada bulan Januari Tahun 1989 M/ Jumadil Akhir 1409 H, ${ }^{16}$ Ust. Muhammad Anwar berwasiat bahwa kepemimpinan Pondok Pesantren Cibadak dilanjutkan oleh A. Muhammad Isa. ${ }^{17}$ Hal ini terjadi bukan tanpa sebab, A. Muhammad Isa dikenal sebagai sosok yang alim dan cerdas, ia menguasai banyak bidang keilmuan, diantaranya: Ilmu Aqidah-akhlak, Fiqih, Ilmu Hadits, Mantiq,

\footnotetext{
13 "Riwayat Singget Apa K.H. A. Muhammad Isa," 2.

14 "Riwayat Singget Apa K.H. A. Muhammad Isa," 1.

15 Alwan, "Wawancara Sehari Dengan Cep Muhammad Ridwan Mengenai K.H. A. Muhammad Isa," 2.

${ }^{16}$ Hitungan kalender Islam (Hijriyah) tahun $1989 \mathrm{M}$ ini berdasarkan kemungkinan Rukyatul Hilal Global yang meliputi tahun Hijriyah: 1409-1410 H

17 "Riwayat Singget Apa K.H. A. Muhammad Isa," 1.
} 
Balaghah, Tafsir, Sejarah, dan Ilmu Falak. ${ }^{18}{ }^{19}$ Ustadz Muhammad Anwar berwasiat kepada A. Muhammad Isa untuk melanjutkan pengajian mingguan para kyai dan para ustadz disetiap hari kamis. Dalam pengajian khusus bagi para kyai dan ustadz ini mengkaji beberapa kitab, diantaranya:

1. Tafsir al-Jalalain, karya Jalaluddin al-Mahali dan Jalaluddin asSuyuthi ${ }^{20}$

2. Tanwirul Qulub, karya Syaikh Muhammad Amin al-Kurdi ${ }^{21}$

3. Minhajul 'Abidin, karya Imam al-Ghazali ${ }^{22}$

4. Minhajut'talibin, karya Imam an-Nawawi; ${ }^{23}$ dan

5. Syarah Alfiyah, karya Ibnu Malik. ${ }^{24}$

Pengajian mingguan bagi para Kiyai bukan hanya dilaksanakan pada hari kamis saja, akantetapi dilaksanakan juga pada setiap hari Minggu. Adapun kitab yang dikaji oleh para kyai tersebut ialah:

1. Tafsir al-Jalalain

2. Fathul Wahhab (Fiqih Syafi'i)

3. Ihya Ulumuddin

4. Shahih al-Bukhari

5. Al-Luma' (Ushul Fiqih)

6. Qowa'idul Luqhatil'arobiyyah; dan

7. Ilmu Hisab Hakiki (Ilmu Falak). ${ }^{25}$

\footnotetext{
18 "Riwayat Singget Apa K.H. A. Muhammad Isa," 4.

19 "Riwayat Singget Apa K.H. A. Muhammad Isa," 1-2.

${ }^{20}$ Muhammad Ibnu Sahroji, "Biografi Jalaluddin As-Suyuthi (849-911 H/1445-1505M):

Karangannya Lebih Dari 500 Kitab," 5 Desember, 2020, https://bincangsyariah.com/khazanah/biografi-jalaluddin-suyuthi-849-911-h-1445-1505-mkarangannya-lebih-dari-500-kitab/.

${ }^{21}$ Wakid Yusuf, "Biografi Pengarang Kitab Tanwirul Qulub Syeikh M. Amin Al-Kurdi," 2 Maret, 2018 , https://www.google.com/amp/s/wakidyusuf.wordpress.com/2018/03/02/biografi-pengarangkitab-tanwirul-qulub-syeikh-m-amin-al-kurdi-/amp/.

${ }^{22}$ Andri Yulian Christyanto, "Metode Self Healing Dalam Kitab Minhajul ‘ Abidin Imam AlGhazali," Jurnal Bimbingan Dan Konseling 6, no. 2 (2021): 188-94, http://jurnal.umtapsel.ac.id/index.php/Ristekdik/article/view/4089/pdf.

${ }^{23}$ Tgk Alizar Usman, "Riwayat Hidup Pengarang Minhaj Al-Thalibin, Imam Al-Nawawi," 20 April 2011, 2011, http://kitab-kuneng.blogspot.com/2011/04/riwayat-hidup-pengarangminhaj-al.html?m=1.

${ }^{24}$ Vina Yunda Safitri, "Menyibak Sisi Lain Karya Monumental Alfiyah Ibnu Malik," Jumat, 01 Oktober 2021 07:30, 2021, https://jatim.nu.or.id/amp/read/menyibak-sisi-lain-karyamonumental-alfiyah-ibnu-malik.

25 "Riwayat Singget Apa K.H. A. Muhammad Isa," 2.
} 
Selain pengajian hari kamis dan hari minggu, diadakan juga kegiatan pengajian bagi para Guru Sekolah Agama dan para kyai setempat pada setiap malam selasa. Adapun kitab yang dikaji pada pengajian tersebut, diantaranya: Tafsir Jalalain dan Shahih Bukhari. Akan tetapi, kitab yang dikaji pada pengajian malam selasa ini dapat berubah sewaktu-waktu. Jika memungkinkan, kitab yang dikaji pada malam itu bisa ditambah dengan kitab al-Mawarits (ilmu faroid), dan Tanzimul Nasl. Kemudian pada setiap satu bulan sekali, tepatnya pada malam kamis di minggu pertama, diadakan pengaian bulanan untuk para Alumnus Pesantren. Adapun kitab yang dikaji pada malam itu ialah: Tafsir al-Wadlih, karya Dr. Mahmud Hijazy ${ }^{26}$; Kitab Maw'idzotul Mu'minin; Shahih Muslim; dan Ilmu mantiq Kitab Sullamul Munawroq. Diadakan juga pengajian khusus bagi perempuan yang dilaksanakan satu minggu sekali, yaitu pada hari selasa pagi. Pengajian khusus perempuan ini membahas tentang Fardhu 'Ain, adapun kajian pembahasan pada pengajian ini meliputi hukum syariah, aqidah, dan akhlak yang bersandar pada kitab Mau'idzotul Mu'minin dan kitab Ihya Ulumuddin. ${ }^{27}$

Sebagai upaya memajukan Pondok Pesantren, dibentuklah Yayasan Pendidikan dan Dakwah Islam "Ihya' Ulumuddin" yang kemudian disingkat "Al Ihya", dengan Akte Notaris tanggal 7 Maret 1991 M, No. 6. Adapun Kurikulum Yayasan Al-Ihya yang diterapkan dalam sistem pendidikan pesantren tersebut yaitu: Pembelajaran tingkat 'Ula, tingkat menengah, dan tingkat Ulya. Selain itu, diadakan juga program Takhassus Fiqh wal Hadits. ${ }^{28}$ Diantara kitab-kitab yang dipelajarinya antara lain: al-Majmu' Syarah alMuhaddzab sejumlah 19 jilid; Mughnil Muhtaj sejumlah 4 jilid; Nihayatul Muntaj sejumlah 8 jilid; Hasyiyah 'Alal Tafsir Jalalain sejumlah 4 jilid; Hasyiyah al-Jamal'ala Syahril Minhaj sejumlah 5 jilid; dan beberapa kitab lainnya. Semua kitab yang dipelajari itu dibubuhi oleh catatan penjelasan serta komentar-komentar isi kitab pada tiap halamannya. ${ }^{29}$

Kiprah A. Muhammad Isa dalam syiar Islamiah tak hanya dilingkup pesantren saja, ia juga aktif dalam berbagai Organisasi Masyarakat (Ormas),

26 Tafsir_Hadits.com, “Tafsir Al-Wadhih," Senin, 31 Desember 2012, 2012, http://tafsirhaditsuinsgdbdgangkatan2009.blogspot.com/2012/12/tafsir-al-wadhih.html?m=1.

27 "Riwayat Singget Apa K.H. A. Muhammad Isa," 1-2.

28 "Riwayat Singget Apa K.H. A. Muhammad Isa," 2.

29 "Riwayat Singget Apa K.H. A. Muhammad Isa," 3. 
seperti Nahdlatul 'Ulama dan Mathla'ul Anwar. ${ }^{30}$ Atas peran aktif dan berbagai kontribusi yang diberikan dalam syiar Islamiah, serta petunjuk dari K.H. Uyeh Balukia Syakir Pengasuh Pondok Pesantren Yamisa Soreang, A. Muhammad Isa menjadi Anggota Badan Hisab dan Rukyat ${ }^{31}$ Kementerian Agama Republik Indonesia, aktif sejak ${ }^{32} 2006-2015$. Ia juga aktif mengarang puluhan tarjamah kitab-kitab berbahasa Arab serta beberapa karangan mengenai Fiqih dan Akidah, diantaranya:

1. Tarjamah Syarah Matan Safinah dalam (bahasa Sunda)

2. Tarjamah Syarah Matan Jurumiyah (bahasa Sunda)

3. Tarjamah Syarah Matan Tijan ad-Darori (bahasa Sunda)

4. Tarjamah Syarah Matan Taqrib (bahasa Sunda)

5. Al-Adillah at-Tawhidiyyah (bahasa Arab)

6. An-Nawafil/Kumpulan Sholat Sunah (Bahasa Sunda)

7. Darusul Hadits an-Nabawi (Bahasa Arab)

8. Tarjamah dan Syarah Bulughul Marom (Bahasa Sunda)

9. Tarjamah dan Syarah Matan Tashrif al-Izzi (Bahasa Sunda)

10. Fiqih Islam (Bahasa Indonesia)

11. Az-Zakaf Fi Syari'atil Islamiyah (Bahasa Arab)

12. AL-Mawarits ( Bahasa Arab)

13. Tarjamah al-Qur'anul 'Adzim

14. Tarjamah Syarah dan Matan Alfiyah

15. Durusul Fiqh (Bahasa Arab)

16. Durusul Lughah al-Arobiyah (Bahasa Arab)

17. Qowaid al-Lughah al-Arobiyah (Bahasa Arab)

18. Pengantar Ilmu Kalam

19. Ilmu Kalam

20. Ilmu Tajwid

21. Al-Adiyat Wal'Adzkar al-Ma'tsurat (Bahasa Sunda)

22. Sarah Jauhal Maknun (Bahasa Arab)

23. Syarah Sullamu Nawraq

\footnotetext{
30 Alwan, "Wawancara Sehari Dengan Cep Muhammad Ridwan Mengenai K.H. A. Muhammad Isa," 2.

31 "Riwayat Singget Apa K.H. A. Muhammad Isa," 4.

${ }^{32}$ Lihat Surat Keputusan Menteri Agama Republik Indonesia Nomor 483 Tahun 2006 Tentang Penunjukan Personalia Badan Hisab Dan Rukyat Departemen Agama Tahun 2006 dan Surat Keputusan Menteri Agama Republik IndonesianNomor 56 Tahun 2010 Tentang Pembentukan Pengurus Badan Hisab Dan Rukyat Kementerian Agama Tahun 2010.
} 


\section{Serial Dakwah Islamiyah}

25. Ringkasan Akidah Islam Ahlussunnahwaljama'ah; dan

26. Fiqih Ibadah yang disertai dengan dalil-dalil al-Qur'an dan pendapat para Ulama, dll. ${ }^{33}$

Lebih kurang selama 32 tahun, ${ }^{34}$ A. Muhammad Isa memimpin Pesantren Al-Ihya Cibadak serta mengabdikan diri untuk membina dan mengajarkan ilmu agama kepada murid-muridnya, menggantikan peran ayahnya yang telah wafat. Dan lebih dari 60 tahun, ${ }^{35}$ ia membimbing masyarakat dengan penuh keikhlasan, menanamkan nilai-nilai moderasi beragama guna terciptanya kehidupan yang rukun dan toleran. Tepat pada pagi hari, 11 April 2021 M, bersamaan dengan 28 Sya'ban 1442 H, Mu'allim K.H. A. Muhammad Isa wafat di RSDH Cianjur, dan dimakamkan di Cibadak, Tanggeung. ${ }^{36}$ Kemudian, kepemimpinan pesantren Al-Ihya Cibadak diteruskan oleh anak keempatnya, yaitu Cep Muhammad Ridwan.

\section{Peran K.H. A. Muhammad Isa dalam Perwujudan Islam Moderat di Cianjur Selatan}

Sebagai seorang tokoh yang mumpuni dalam Ilmu Agama, A. Muhammad Isa bukan hanya sebatas seorang pendidik saja, namun juga dijadikan sebagai sosok panutan karena begitu luhur tingkat keilmuan yang dimilikinya. Tidak hanya dikalangan santri dan masyarakat saja, diantara sesama kyai pun, K.H. A. Muhammad Isa mendapat tempat yang istimewa, bahkan sangat dihormati. Tentunya hal ini terjadi bukan tanpa sebab, sikap alim, toleran, serta kehati-hatiannya dalam bertindak dan menyikapi segala persoalan maupun perbedaan paham turut mendasari citra pribadinya sebagai seorang kyai yang mumpumi dan penuh kharismatik. Dalam hal menyikapi perbedaan madzhab maupun fiqih, sikap toleransi yang tinggi tidak membuatnya bersikap fanatik terhadap ajaran yang ia yakini. Ia tetap memegang teguh fiqih Madzhab Syafi'i tanpa harus menyalahkan maupun mempermasalahkan perbedaan fiqih dengan yang ada di lingkungannya.

\footnotetext{
33 "Riwayat Singget Apa K.H. A. Muhammad Isa," 4.

${ }^{34}$ Hitungan waktu ini berdasarkan tahun wafat ayahnya, Ust. Muhammad Anwar.

35 "Riwayat Singget Apa K.H. A. Muhammad Isa," 5.

${ }^{36}$ Ferri Amiril Mukminin, "Innalillahi, Ulama Falak Asal Cianjur Yang Sering dilibatkan Dalam Menentukan Ramadhan Meninggal Dunia,” Minggu, 11 April pukul 09:15, 2021, https:/www.google.com/amp/s/jabar.tribunnews.com/amp/2021/04/11/innalillahi-ulamafalak-asal-cianjur-yang-sering-dilibatkan-dalam-menentukan-awal-ramadan-meninggal .
} 
Sedangkan dalam akidah, ia menggunakan Akidah Asy'ariyah dan Maturidiyah (Ahlussunah wal Jamaah). Sebagai seorang pendidik, dapat dikatakan sangat berhasil karena pengaruh kepemimpinannya. Sampai saat ini, pengaruhnya masih sangat besar, baik terhadap para kyai dan cendekiawan muslim, masyarakat dan organisasi masyarakat (Ormas), maupun terhadap pemerintahan. ${ }^{37}$

Dalam perjalanannya, A. Muhammad Isa berpandangan bahwa dalam rangka mensyiarkan ajaran islam, tentunya harus relevan dengan keadaan zaman. Menurutnya, pendidikan pesantren tidak bisa bersikukuh mempertahankan anggapan bahwa pendidikan formal merupakan model Pendidikan Barat yang tidak sejalan dengan tradisi pesantren, sehingga timbulnya jurang pemisah antara pendidikan formal dengan pendidikan pesantren. Oleh karena itu, munculah sebuah terobosan yang adaptif terhadap kebutuhan di lingkungan masyarakat, diantaranya dengan mendirikan Madrasah Tsanawiyah (MTs) pada sekitar tahun 1996 M, dan Madrasah Aliyah (MA) pada tahun 2006 M. Ia sangat yakin bahwa pendidikan formal disamping pendidikan pesantren sangatlah penting adanya, hal ini ia yakini sebagai salah satu upaya untuk merespon tuntutan zaman. Berbanding terbalik dengan mayoritas kyai pada masa itu yang masih berpegang teguh pada prinsip konservatif; menjalankan syariat Islam dengan fanatik dan menganggap bahwa segala sesuatu yang tidak berasal dari dunia Islam merupakan hal yang keliru bahkan bertentangan, termasuk pendidikan formal sekalipun. Walau pun pada tahun 1980-an Umat Islam di Indonesia terbilang sudah cukup moderat, akan tetapi dalam praktiknya, pemikiran konservatif masih sangat melekat kuat dikalangan beberapa tokoh ulama dan kyai pada waktu itu. Di samping mendirikan Madrasah formal guna merespon tuntutan zaman, A. Muhammad Isa turut andil dalam mengisi materi pembelajaran di kelas, ia menjadi guru matapelajaran muatan lokal (Mulok) dan pengembangan diri, diantaranya: kitab kuning, kitab fiqih, ilmu falak, dan beberapa kitab lain yang telah ia buat. ${ }^{38}$

Selain dikenal sebagai kyai yang berpengetahuan tinggi dalam Ilmu Agama, A. Muhammad Isa juga dikenal sebagai seorang pribadi yang patuh dan taat terhadap ajaran agama, giat mensyiarkan syariat Islam kepada sesama

\footnotetext{
37 Alwan, "Wawancara Sehari Dengan Cep Muhammad Ridwan Mengenai K.H. A. Muhammad Isa," 2.

${ }^{38}$ Alwan, 2.
} 
umat, berjuang sebagai penerang bagi masyarakat. Sebagai bentuk kebrilianannya sebagai seorang lama, ia banyak mengarang tulisan tentang fiqih dan akidah, serta membuat tukilan syarah kitab-kitab berbahasa Arab, sehingga mudah dimengerti dan menyebarluas dikalangan para Ulama Kabupaten Cianjur. ${ }^{39}$ Kiprahnya sebagai ulama dan cendekiawan muslim tak cukup sampai di situ. Pada tahun $2006,{ }^{40}$ ia menjadi salah satu anggota Badan Hisab dan Rukyat Republik Indonesia, sebagai perwakilan dari Mathlaul Anwar. Status keanggotaan sebagai Anggota Badan Hisab dan Rukyat ini berlangsung hingga beberapa tahun kemudian. ${ }^{41}$ Prestasi gemilang yang ia peroleh ini tidak terlepas dari sikap moderat dan toleransi yang tinggi, sehingga membuatnya senantiasa mendapatkan posisi terbaik sebagai seorang ulama yang berdedikasi untuk kepentingan dan kemajuan umat Islam.

Sebagai tokoh masyarakat, ia berpedoman pada prinsip "Uswatun Hasanah", yang mana keteladanan sangat ia utamakan dan kepemimpinan Rasulullah SAW. sangat mempengaruhi cara ia memimpin umat. Jika bulan Rabiul Awal dan bulan Rajab tiba, A. Muhammad Isa selalu diminta untuk mengisi atau menyampaikan dakwah Islamiah pada acara Maulid Nabi Muhammad SAW. maupun dalam acara Isra' Mi'raj Rasulullah SAW. di berbagai tempat. ${ }^{42}$ Corak penyampaian dakwanya yang khas, ${ }^{43}$ membuat siapa saja yang mendengarnya seakan ikut terhanyut ke dalamnya. Cara penyampaiannya yang tidak menggurui berhasil menarik simpati audien sehingga sangat mudah diterima. Dalam menyampaikan ceramahnya, ia selalu menyampaikannya melalui penuturan peristiwa Sejarah Islam serta kepribadian Rasulullah SAW. ia memberi persuasif terhadap masyarakat melalui suri tauladan yang digambarkan pada kisah sejarah Rasulullah SAW. Metode dakwah ini terbukti sangat efektif, karena dengan metode ini,

\footnotetext{
39 Mukminin, "Innalillahi, Ulama Falak Asal Cianjur Yang Sering Dilibatkan Dalam Menentukan Ramadhan Meninggal Dunia."

${ }^{40}$ Menteri Agama Republik Indonesia, "Keputusan Menteri Agama Republik Indonesia Nomor 483 Tahun 2006 Tentang Penunjukan Personalia Badan Hisab Dan Rukyat Departemen Agama Tahun 2006.”

${ }^{41}$ Lihat Surat Keputusan Menteri Agama Republik Indonesia Nomor 483 Tahun 2006 Tentang Penunjukan Personalia Badan Hisab Dan Rukyat Departemen Agama Tahun 2006 dan Surat Keputusan Menteri Agama Republik IndonesianNomor 56 Tahun 2010 Tentang Pembentukan Pengurus Badan Hisab Dan Rukyat Kementerian Agama Tahun 2010.

42 "Riwayat Singget Apa K.H. A. Muhammad Isa," 4.

${ }^{43}$ Ulumuddin, Ceramah Sunda Oleh K.H. Acep Muhammad Isa/ Apa Cibadak v2 (Al-Ihya Cibadak, Tanggeung) (Indonesia, n.d.), https://www.youtube.com/watch?app=desktop\&v=I7cNK8M3erQ.
} 
masyarakat sangat mudah menerima karena tidak ada yang tersinggung atas pesan-pesan yang di sampaikan. ${ }^{44}$

Untuk mempermudah akses komunikasi serta memperoleh informasi dengan cepat, A. Muhammad Isa turut memanfaatkan perkembangan teknologi sebagai sarana yang tepat. Ia sadar bahwa modernisasi adalah kenyataan yang tidak dapat dielakan lagi, dan bukan suatu hal yang harus di hindari, karena perkembangan teknologi informasi dan komunikasi bukan merupakan sesuatu yang negatif apabila dimanfaatkan dengan sebaik mungkin. Sebagai contoh, untuk menunjang efektifitas pembelajaran, A. Muhammad Isa kerap kali menggunakan media sosial (medsos) dalam berkomunikasi ataupun meyampaikan materi pembelajaran pesantren dan sekolah kepada para santri maupun siswanya. ${ }^{45}$

\section{Simpulan}

K.H. A. Muhammad Isa adalah cendekiawan muslim yang sangat gigih dalam mencetak generasi muda Islami yang moderat. Ia lahir di Sindangbarang pada tanggal 30 September 1930/ 7 Jumadil Awal 1349 H, putra dari pasangan Ust. Muhammad Anwar dan $\mathrm{Hj}$. Nuriyah. Pasca kelahirannya, sang kakek, H. Tohir menyematkan nama Acep Isa Hidayat untuknya. A. Muhammad Isa dibawa oleh ibunya ke Cihamirung untuk tinggal dan menetap di sana sampai usia tiga tahun. Setelah mencapai usia tiga tahun, A. Muhammad Isa dibawa oleh kakenya, H. Tohir ke Sindaangbarang untuk tinggal dan menetap bersamanya.

Bersama sang kakek, A. Muhammad Isa memperoleh pendidikan umum melalui Sekolah Rakyat (SR), serta pendidikan keagamaan di Madrasah Diniyah Takmiliyah Awaliyah (DTA), yang di asuh oleh mualim Zarqani. Setelah menamatkan pendidikan di Sekolah Rakyat (SR) dan Madrasah Diniyah Takmiliyah Awaliyah (DTA), atas petunjuk dan saran dari sang kakek, A. Muhammad Isa berangkat ke Cibadak untuk menemui ayahnya, Ust. Muhammad Anwar guna memperoleh pendidikan agama lebih mendalam. Saat itu, Ust. Muhammad Anwar merupakan guru sekaligus pengasuh Pondok Pesantren Cibadak. A. Muhammad Isa menguasai banyak bidang keilmuan, mulai dari ilmu fiqih, akidah-akhlak, mantiq, falak, dan bidang keilmuan

\footnotetext{
44 Alwan, "Wawancara Sehari Dengan Cep Muhammad Ridwan Mengenai K.H. A. Muhammad Isa," 1.

45 Alwan, 1.
} 
lainnya. Ia aktif di berbagai organisasi masyarakat maupun dalam bidang politik. Ia aktif menjadi bagian dari Nahdlatul Ulama (NU) di samping Mathlaul Anwar. Atas kebrilianannya, ia menjadi Anggota Badan Hisab dan Rukyat Kementerian Agama Republik Indonesia. Dengan demikian, ia senantiasa dilibatkan dalam penentuan awal Ramadhan dan satu Syawal.

Tepat pada tanggal 11 April $2021 \mathrm{M}$, bersamaan dengan 28 Sya'ban 1442 H, Mu'allim K.H. A. Muhammad Isa wafat di RSDH Cianjur, dan dimakamkan di Cibadak, Tanggeung, Cianjur. Walau ia telah wafat, pengaruh dan ajaran yang selalu ia sampaikan tetap hidup melalui murid-muridnya yang tersebar diseluruh pelosok Cianjur. Kemudian pasca wafatnya A. Muhammad Isa, kepemimpinan pesantren Al-Ihya Cibadak diteruskan oleh anak keempatnya, yaitu Cep Muhammad Ridwan.

\section{Daftar Sumber}

\section{Buku}

Maarif, Syamsudin, Kamal. "Satu Islam Banyak Jalan: Corak-Corak Pemikiran Modern Dalam Islam." In Satu Islam Banyak Jalan: CorakCorak Pemikiran Modern Dalam Islam, edited by Amin Nurdin, 6. Yogyakarta: Pustaka Pelajar, 2020.

Priyadi, Sugeng. Sejarah Lokal: Konsep, Metode, Dan Tantangannya. Edited by Dian Qamajaya. Yogyakarta: Ombak, 2015.

\section{Jurnal}

Christyanto, Andri Yulian. "Metode Self Healing Dalam Kitab Minhajul ‘ Abidin Imam Al-Ghazali." Jurnal Bimbingan Dan Konseling 6, no. 2 (2021): $188-94$. http://jurnal.umtapsel.ac.id/index.php/Ristekdik/article/view/4089/pdf.

Hannan, Abd, Departemen Sosiologi, Fakultas Ilmu, Ilmu Politik, Universitas Airlangga, and Jawa Timur. "Islam Moderat Dan Tradisi Popular Pesantren : Strategi Penguatan Islam Moderat Di Kalangan Masyarakat Madura Melalui Nilai Tradisi Popular Islam Berbasis Pesantren Moderate Islam and Popular Pesantren Tradition: Strategy for Strengthening Moderate Islam." Jurnal Sosiologi Dialektika 13, no. 2 (2018): 152-68. https://ejournal.unair.ac.id/DIALEKTIKA/article/view/19149. 


\section{Kertas Kerja}

Alwan. "Wawancara Sehari Dengan Cep Muhammad Ridwan Mengenai K.H. A. Muhammad Isa." Cianjur, October 10, 2021.

\section{Surat Elektronik}

Menteri Agama Republik Indonesia. "Keputusan Menteri Agama Republik Indonesia Nomor 483 Tahun 2006 Tentang Penunjukan Personalia Badan Hisab Dan Rukyat Departemen Agama Tahun 2006.” Jakarta, 2006. https://www.google.com/search?q=penetapan+anggita+bafan+hisab+da $\mathrm{n}+$ rukyat $+2006 \&$ oq $=$ penetapan + anggita + bafan + hisab + dan + rukyat +200 $6 \&$ aqs $=$ chrome..69i57.10003j0j9\&client $=$ ms-androidsamsung\&sourceid $=$ chrome-mobile\&ie $=U T F-8$.

- "Keputusan Menteri Agama Republik Indonesia Nomor 56 Tahun 2010 Tentang Pembentukan Pengurus Badan Hisab Dan Rukyat Kementerian Agama Tahun 2010.” Jakarta, 2010. https://www.google.com/url?sa=t\&source=web\&rct=j\&url=https://kepri .kemenag.go.id/public/files/kmapma/szqx1419410452.pdf\&ved=2ahU KEwi4wsah95f0AhVQWX0KHQOOCuoQFnoECAYQAQ\&usg=AOv Vaw3z6GIOVSeltshWpIPVQXj6.

\section{Konten Situs Web}

Hidayatullah, Syarif. "R. Muhammad Isa, Ulama Falak Cianjur Meninggal Dunia.” $11 \quad$ April, 2021. https://www.google.com/amp/s/pakuanraya.com/r-muhammad-isaulama-falaq-cianjur-meninggal-dunia/amp/.

Mukminin, Ferri Amiril. "Innalillahi, Ulama Falak Asal Cianjur Yang Sering Dilibatkan Dalam Menentukan Ramadhan Meninggal Dunia.” Minggu, 11 April pukul 09:15, 2021. https://www.google.com/amp/s/jabar.tribunnews.com/amp/2021/04/11/i nnalillahi-ulama-falak-asal-cianjur-yang-sering-dilibatkan-dalammenentukan-awal-ramadan-meninggal .

Novita, Cicik. "Memahami Makna Menuntut Ilmu Dan Keutamaanya Dalam Islam." 30 Mei, 2021. https://www.google.com/amp/s/amp.tirto.id/memahami-maknamenuntut-ilmu-dan-keutamaannya-dalam-islam-ggpX . 
"Riwayat Singget Apa K.H. A. Muhammad Isa." Cianjur, 2020.

Safitri, Vina Yunda. "Menyibak Sisi Lain Karya Monumental Alfiyah Ibnu Malik." Jumat, $01 \quad$ Oktober 2021 07:30, 2021. https://jatim.nu.or.id/amp/read/menyibak-sisi-lain-karya-monumentalalfiyah-ibnu-malik.

Sahroji, Muhammad Ibnu. "Biografi Jalaluddin As-Suyuthi (849-911 H/14451505M): Karangannya Lebih Dari 500 Kitab." 5 Desember, 2020. https://bincangsyariah.com/khazanah/biografi-jalaluddin-suyuthi-849911-h-1445-1505-m-karangannya-lebih-dari-500-kitab/.

Tafsir_Hadits.com. “Tafsir Al-Wadhih.” Senin, 31 Desember 2012, 2012. http://tafsirhaditsuinsgdbdgangkatan2009.blogspot.com/2012/12/tafsiral-wadhih.html?m=1.

Tagar.id. "Gus Dur Dan Empat Tokoh Islam Moderat Asal Indonesia." 22 Agustus, 2019. https://www.tagar.id/gus-dur-dan-empat-tokoh-islammoderat-asal-indonesia\%0A\%0A.

Ulumuddin. Ceramah Sunda Oleh K.H. Acep Muhammad Isal Apa Cibadak v2 (Al-Ihya Cibadak, Tanggeung). Indonesia, n.d. https://www.youtube.com/watch?app=desktop\&v=I7cNK8M3erQ.

Usman, Tgk Alizar. "Riwayat Hidup Pengarang Minhaj Al-Thalibin, Imam Al-Nawawi." $20 \quad$ April 2011, 2011. http://kitabkuneng.blogspot.com/2011/04/riwayat-hidup-pengarang-minhajal.html? $\mathrm{m}=1$.

Yusuf, Wakid. "Biografi Pengarang Kitab Tanwirul Qulub Syeikh M. Amin Al-Kurdi." 2 Maret, 2018. https://www.google.com/amp/s/wakidyusuf.wordpress.com/2018/03/02/ biografi-pengarang-kitab-tanwirul-qulub-syeikh-m-amin-al-kurdi/amp/. 